\title{
Studies on Seminal Attributes of Neat Semen of Hariana Bulls
}

\author{
Ajendar Singh Pal ${ }^{1}$, Vijay Singh ${ }^{2 *}$ and Akhil Patel ${ }^{2}$ \\ ${ }^{1}$ Department of Veterinary Obstetrics and Gynaecology, U.P. Pt. Deen Dayal Upadhyaya \\ Pashu Chikitsa Vigyan Vishwavidyalaya Evam Go Anusandhan Sansthan, \\ Mathura, Uttar Pradesh, India \\ ${ }^{2}$ Department of Veterinary Gynaecology and Obstetrics, College of Veterinary and Animal \\ Sciences, S.V.P.U.A.T., Meerut, Uttar Pradesh-250110, India \\ *Corresponding author
}

\section{Keywords}

Mass motility,

Progressive

motility, Sperm concentration, Total morphological sperm abnormalities

Article Info

Accepted:

15 December 2019

Available Online:

20 January 2020

\section{A B S T R A C T}

The mean \pm S.E. values of seminal attributes evaluated for assessing the quality of freshly ejaculated neat semen from four Hariana bulls has been estimated. In the present study mean ejaculate semen volume ranges between $3.35 \pm 0.14$ to $5.38 \pm 0.20 \mathrm{ml}$. Semen mass motility $(0-5$ scale $)$ ranges between $3.13 \pm 0.08$ to $3.69 \pm 0.09$. Sperm concentration varies significantly among the four Hariana bulls and ranges between $1633.50 \pm$ 33.58 to $1806.25 \pm 31.56 \mathrm{millions} / \mathrm{ml}$. Present study indicated that the percent sperm progressive motility amongst four Hariana bulls range between $72.00 \pm 1.21$ to $78.13 \pm 1.28$. Percent live sperm in the ejaculate varies significantly among the four Hariana bulls and ranges between 80.12 \pm 1.70 to $87.13 \pm 1.49$. The mean percent total morphological sperm abnormalities of the four Hariana bulls varies between $3.50 \pm 0.42$ to $4.13 \pm$ 0.35 indicating that all bulls are within the permissible limit of abnormalities and is suitable for cryopreservation.

\section{Introduction}

India is predominantly an agricultural country with about $70 \%$ of its population dependent on income from agriculture. Animal husbandry is an adjunct to crop agriculture and Cattle, buffaloes are kept for milk production. Cattle farming are one of the major sources of income for majority of population in India. Cattle farming have played a very important role in growth of Indian economy. India has achieved top position in milk production of world producing about 109 millions tones of milk with $4.5 \%$ annual growth rate of milk (Economic Survey 2009-10). Cattle contribute about $45 \%$ of the country total milk production which have been possible due to 
availability of many milch breeds. India continues to be the largest milk producing nation in the world with close to $17 \%$ of global production in 2010-11. As per the figures of $18^{\text {th }}$ Livestock Census, India has 199.07 million Cattle (33.06 million crossbred cattle and 166.01 million indigenous breed). India contributes its $12.7 \%$ of total world Cattle population and 2nd rank in Cattle population in the world.

Hariana Cattle (Bos indicus) derived their name from the tract most probably "hari (green)". Hariana breed of Cattle is known for its dual purpose, among the Zebu Cattle. The native tract of this breed is Rohtak, Hisar, Gurgaon, Karnal, Delhi. This breed also exists in more or less pure form in Jind, Patiala, Jaipur, Jodhpur and western U.P. Uttar Pradesh has maximum number of Hariana Cattle than any other breed $\left(18^{\text {th }}\right.$ Livestock Census, India; Uttar Pradesh Census). The breed averages $1700 \mathrm{~kg}$ of milk per lactation but high producing animals has produced over $2500 \mathrm{~kg}$ in a single lactation. The males (Bullock) of this breed have been used as a powerful tool for transportation and ploughing. Depleting source of petroleum products being used in agriculture sector, there is a need for conservation of this breed.

Artificial insemination has been used exhaustively to facilitate the best use of elite bulls with proven fertility. It has tremendously improved the genetic makeup and ultimately productivity of low productive indigenous breeds in India. The results of artificial insemination depend upon the quality of semen produced and it is mainly dependent on the managemental practices adopted at bull semen collection centre (Corona et al., 2006). The prime objective of artificial insemination is to improve breeds to obtain optimum milk production and it is possible only by quality semen. Keeping it in view, the present study was planned to assess seminal attributes on Neat semen of Hariana bulls.

\section{Materials and Methods}

Present study was conducted on four Hariana bulls of the age group between 4.5 to 5.5 years and weighing more than $400 \mathrm{~kg}$ body weight, reared at the University Instructional Livestock Farm Complex (ILFC), College of Veterinary Science and Animal Husbandry, U.P. Pandit Deen Dayal Upadhayaya Pashu Chikitsa Vigyan Vishwavidyalaya Evam Go Anusandhan Sansthan, Mathura.

\section{Evaluation of semen}

Semen was evaluated based on the following parameters.

\section{Volume}

The volume of semen was directly measured in milliliter $(\mathrm{ml})$ in the graduated centrifuge semen collection tube.

\section{Colour}

Semen sample were observed for colour and consistency by direct visualization with naked eyes and any abnormalities in colour or consistency were treated as abnormal and the sample were discarded.

\section{Mass motility}

It was assessed by method of Nazir, (1988) reported in Nili-ravi buffalo that motility was rated according to the vigour wave motion on grade scale of 0 to 5 .

\section{Progressive motility}

The progressive motility of the spermatozoa calculated as per method of Ahmad, (1994). 


\section{Sperm concentration}

Sperm concentration was estimated using Improved Neubauer's chamber method (Salisbury et al., 1978).

\section{Live and dead spermatozoa count}

Method described by Bloom (1950) and Hancock (1951) was followed.

\section{Morphological Abnormalities}

Live and dead count was also used for enumerating abnormalities. The classification suggested by (Lasley, 1951) was used for the study.

\section{Hypo-osmotic swelling test (HOST)}

The hypo-osmotic swelling test was performed according to the methods described by Correa and Zavos (1994). A pinch of nigrosin was added in both HOST and Control solution to provide background to facilitate counting. These spermatozoa were classified in four different classes according to presence of swelling pattern (Takahasi et al., 1990).

\section{Acrosome integrity}

Staining was carried out as described by Hancock (1952).

\section{Results and Discussion}

The mean \pm S.E. values of seminal attributes evaluated for assessing the quality of freshly ejaculated neat semen from four Hariana bulls has been estimated. The ejaculated semen collected from four Hariana bulls were evaluated for their volume $(\mathrm{ml})$, mass motility (0-5 scale), sperm concentration (millions/ml), progressive motility (percent), live sperm (percent) and total sperm abnormalities (percent). The relevant data has been illustrated in Table 1.

\section{Semen volume}

Semen volume is an important parameter as the number of breeding doses of A.I. depends on the ejaculate semen volume and sperm concentration. In the present study indicated that the mean ejaculate semen volume varies significantly among the four Hariana bulls and ranges between $3.35 \pm 0.14$ to $5.38 \pm 0.20$ ml. In a similar study (Kumar, 2011 and Singh, 2012) in Hariana bulls the mean ejaculate volume was reported to range between $2.85 \pm 0.21$ to $5.65 \pm 0.39 \mathrm{ml}$. The results for this parameter confirm the earlier report and are in the reported range. Further, other reports suggest the range of ejaculate semen volume to vary between $3.3 \mathrm{ml}$ to 5.3 $\mathrm{ml}$ for Hariana bulls (Shukla and Bhattacharya, 1949; Tomar et al., 1966; Tomar and Kanaujia, 1970; Tomar and Gupta, 1984) which is in agreement with our reported values.

Variation in semen volume has been reported among different species and within a species and even the same male at different time of collection. The volume of semen was reported to vary with breed, age (Rao and Shreemanarayana, 1996), body size, size of accessory sex gland (White, 1975), frequency of collection, exercise, teasing, level of nutrition, effect of season (Saxena and Tripathi, 1981 and Dhami et al., 1998), and method of collection. In the present studies the other factors responsible for variation of semen volume are same for all bulls except that level of teasing could have been a factor for variation in semen volume.

\section{Mass motility}

Sperm motility gives the first hand information regarding the fertilizing capacity 
of semen. Sperm motility is crucial in facilitating passage through the cervix and utero-tubal junction and much more important in actual penetration of the cumulus cells and zona pellucida of the ovum (Hafez, 1987). However, Erb et al., (1956) demonstrated that it is more closely related with other seminal traits than fertility. The mass motility of spermatozoa is a wholesome effect of sperm concentration and individual motility (Zemjanis, 1970).

Present study indicated that semen mass motility (0-5 scale) varies significantly among the four Hariana bulls and ranges between $3.13 \pm 0.08$ to $3.69 \pm 0.09$. In a similar study (Kumar, 2011 and Singh, 2012) in Hariana bulls the semen mass motility ranges between $3.20 \pm 0.08$ to $4.35 \pm 0.07$. The results for this parameter mostly similar the earlier report and are in the reported range. Further, other reports suggest the range of semen mass motility was in accordance with the values reported in others cattle bulls by various authors (Tomar et al., 1966; Bhosrekar and Nagpaul, 1972; Rao et al., 1996). Tomar and Gupta (1984) reported mass motility in Hariana bull semen between $3.8 \pm 0.2$ and 4.3 \pm 0.2 in summer and winter season. These values are in close proximity with our results although we have not reported our findings in season. The present study was carried out between February to August.

The semen motility is affected by improper handling procedure, contaminated glasswares (presence of soap residue), chemicals present over the fingers, cold or hot test tubes, glass slides, microscope stage, rapid drying or cooling of glass slides, prolongation during collection and examination period etc.

\section{Sperm concentration}

Accurate determination of the number of spermatozoa per milliliter of semen is extremely important. The sperm concentration is highly variable semen characteristics and when combined with ejaculated semen volume it determines number of females that can be inseminated with optimal number of sperm cells (Hafez, 1987).

Present study indicated that the sperm concentration varies significantly among the four Hariana bulls and ranges between $1633.50 \pm 33.58$ to $1806.25 \pm 31.56$ millions/ml. In a similar study (Kumar, 2011 and Singh, 2012) in Hariana bull semen the sperm concentration (millions $/ \mathrm{ml}$ ) ranges between $938.60 \pm 41.39$ to $2890.0 \pm 118.51$ which was differ compare to the present investigation. These results differ due to effect of age as well as of the season (Das et al., 2007). Sperm concentration (millions $/ \mathrm{ml}$ ) in Hariana bulls different authors are reported as $1150 \pm 53.44$ (Tomar et al.,1966), $1185 \pm$ 65.11(Tomar and Kanaujia, 1970) ,1187 \pm 87.81(Kerur, 1971), $1089 \pm 102.14$ (Singh and Pangawkar,1990), $1225 \pm 29.75$ (Veerapandian et al., 1992) and $1232.5 \pm 41.4$ (Dabas et al., 1982). Our results for sperm concentration are quiet superior compare to these reports. A slight difference in semen concentration may be due to degree of sexual stimulation.

\section{Individual progressive motility}

A drop of ejaculated semen was diluted immediately after collection to observe the progressive motility of spermatozoa. When normal semen has been handled properly and staining is carried out correctly, the percentage of live sperm is highly correlated with percent individual progressive motility, but the percentage of progressive motility is usually lower than the percentage of live spermatozoa as many of the live sperm may not have motile (Hafez, 1987). Individual sperm progressive motility is an important criterion of semen quality (Lasley, 1951) and 
is an important determinant of success rate of the fertilization. Progressive sperm motility, though variable and subjective methods of semen evaluation has been found to be correlated with various semen characteristics (Tomar, 1984). However, Bloom (1950) also reported that motility below 50 percent was often associated with low conception rate and poor fertility. Erb et al., (1956) also demonstrated that it is more closely related in other seminal traits than fertility and suggested that, the bovine semen with 40 to 50 percent motile sperm should be considered as subnormal and was associated with infertility. Branton et al., (1951) opined a minimum initial sperm motility of 70 percent required for an effective breeding. However, a decrease in sperm motility is observed in disease condition, change of environment and temperature variations and it fluctuates between breeds, individuals, age group and technique employed for observation.

Present study indicated that the percent sperm progressive motility amongst four Hariana bulls varies significantly and was in the range between $72.00 \pm 1.21$ to $78.13 \pm 1.28$. Our finding agreement with earlier reports which suggested percent progressive motility ranges between $73.00 \pm 1.11$ to $80.00 \pm 0.00$ (Kumar, 2011 and Singh, 2012).The present result showed that semen samples suitable for further processing of cryopreservation.

\section{Percent live sperm}

Tomar, (1984) reported that live sperm can be predicted by initial motility of semen yet actual evaluation of live sperm is desirable. Semen sample having less than 50 percent live sperm are of questionable fertilizing capacity where as samples containing 50-90 percent live spermatozoa showed no difference in fertilizing capacity. Pant et al., (2002) reported that semen with more than 30 percent initial dead spermatozoa is not good for preservation. Keeping these reports in consideration, in the present study all semen samples which were having more than 70 percent live sperm was subjected to cryopreservation. The percentage of stained spermatozoa is dependent on various factors like duration, type of diluents used, stain integrity and technique employed. Moreover, it gives vital information regarding the livability of both neat and extended semen.

Present study indicated that the percent live sperm in the ejaculate varies significantly among the four Hariana bulls and ranges between $80.12 \pm 1.70$ to $87.13 \pm 1.49$. The neat semen viability in the present experiment was within the optimum range. Our finding is in agreement with earlier reports where percent live sperm ranges between $85.89 \pm$ 1.16 to $90.03 \pm 0.83$ (Kumar, 2011 and Singh, 2012). Further, other reports were in accordance with the values reported in others cattle bulls as percent live sperm $79.86 \pm 0.98$ in cross breed bull (Vyas et al., 1992), 86.20 \pm 1.40 in Murrah bulls (Meena et al., 2010), $80.70 \pm 1.20$ to $87.30 \pm 2.50$ in Sahiwal bull (Ansari et al., 2011), $82.75 \pm 0.02$ to $82.92 \pm$ 0.01in Cattle (Amrendra et al., 2011).

Comparing this result with the result of percent progressive motility of spermatozoa clearly reflects that some of the live spermatozoa was not motile.

\section{Total morphological sperm abnormalities}

Semen from most males contains some abnormally formed spermatozoa which are not associated with lower fertility rates until the proportion of abnormal sperm exceeds 20 percent (Hafez, 1987). Moreover, the sperm abnormality may vary due to method of collection, temperature shock (Hancock, 1952) and technique employed (Bishop et al., 1954). 
Table.1 Seminal attributes of Hariana bull spermatozoa in neat semen (Mean \pm S.E., $n=8$ )

\begin{tabular}{|c|c|c|c|c|c|c|}
\hline Bull No. & Volume (ml) & $\begin{array}{l}\text { Mass Motility } \\
\text { ( } 0 \text {-5 scale) }\end{array}$ & $\begin{array}{l}\text { Concentration } \\
\text { (millions/ ml) }\end{array}$ & $\begin{array}{l}\text { Progressive } \\
\text { motility } \\
(\%)\end{array}$ & $\begin{array}{l}\text { Live sperm } \\
(\%)\end{array}$ & $\begin{array}{c}\text { Total morphoological } \\
\text { sperm Abnormalities } \\
(\%)\end{array}$ \\
\hline H-623 & $\begin{array}{l}5.38^{\mathrm{b}} \pm 0.20 \\
(4.5-6.2)\end{array}$ & $\begin{array}{l}3.69^{\mathrm{b}} \pm 0.09 \\
(3.5-4)\end{array}$ & $\begin{array}{c}1806.25^{\mathrm{b}} \pm 31.56 \\
(1700-1970)\end{array}$ & $\begin{array}{c}78.13^{\mathrm{b}} \pm 1.28 \\
(72-82)\end{array}$ & $\begin{array}{c}86.13^{b} \pm 1.27 \\
(78-90)\end{array}$ & $\begin{array}{c}3.50 \pm 0.42 \\
(2-5)\end{array}$ \\
\hline H- 580 & $\begin{array}{l}5.04^{\mathrm{b}} \pm 0.34 \\
(3.2-6.2)\end{array}$ & $\begin{array}{l}3.63^{\mathrm{b}} \pm 0.08 \\
\quad(3.5-4)\end{array}$ & $\begin{array}{c}1791.25^{b} \pm 27.02 \\
(1700-1940)\end{array}$ & $\begin{array}{c}77.63^{b} \pm 1.26 \\
(71-83)\end{array}$ & $\begin{array}{c}87.13^{b} \pm 1.49 \\
(78-92)\end{array}$ & $\begin{array}{l}3.75 \pm 0.49 \\
\quad(2-6)\end{array}$ \\
\hline H-609 & $\begin{array}{c}3.70^{\mathrm{a}} \pm 0.18 \\
(3.0-4.5)\end{array}$ & $\begin{array}{c}3.19^{\mathrm{a}} \pm 0.09 \\
(3-3.5)\end{array}$ & $\begin{array}{c}1641.75^{\mathrm{a}} \pm 26.43 \\
(1490-1720)\end{array}$ & $\begin{array}{c}73.63^{\mathrm{a}} \pm 1.13 \\
(70-80)\end{array}$ & $\begin{array}{c}80.89^{a} \pm 1.70 \\
(75-90)\end{array}$ & $\begin{array}{c}4.13 \pm 0.35 \\
\quad(2-5)\end{array}$ \\
\hline H-470 & $\begin{array}{c}3.35^{\mathrm{a}} \pm 0.14 \\
(3.0-4.2)\end{array}$ & $\begin{array}{l}3.13^{\mathrm{a}} \pm 0.08 \\
\quad(3-3.5)\end{array}$ & $\begin{array}{c}1633.50^{\mathrm{a}} \pm 33.58 \\
(1500-1780)\end{array}$ & $\begin{array}{l}72.00^{\mathrm{a}} \pm 1.21 \\
(68-78)\end{array}$ & $\begin{array}{c}80.12^{a} \pm 1.70 \\
\quad(75-90)\end{array}$ & $\begin{array}{l}4.00 \pm 0.26 \\
(2-5)\end{array}$ \\
\hline F-Value & $18.48^{* *}$ & $11.23^{* *}$ & $9.79^{* *}$ & $6.00^{* *}$ & $5.11^{\text {** }}$ & $0.50^{\mathrm{NS}}$ \\
\hline Overall & $\begin{array}{c}4.37 \pm 0.19 \\
(3-6.2)\end{array}$ & $\begin{array}{c}3.40 \pm 0.06 \\
(3-4)\end{array}$ & $\begin{array}{c}1718.18 \pm 20.27 \\
(1490-1970)\end{array}$ & $\begin{array}{c}75.34 \pm 0.75 \\
(68-83)\end{array}$ & $\begin{array}{c}83.56 \pm 0.93 \\
(75-92)\end{array}$ & $\begin{array}{c}3.84 \pm 0.19 \\
(2-6)\end{array}$ \\
\hline
\end{tabular}

Means bearing different superscripts in a column (a,b,c) differ significantly. **: significant $(\mathrm{P}<0.01)$

NS: Non significant.

$\mathrm{n}=$ no. of total ejaculates. 
In the present study, the overall sperm abnormality includes head, mid piece and tail abnormality. The mean percent total morphological sperm abnormalities of the four Hariana bulls varies between $3.50 \pm 0.42$ to $4.13 \pm 0.35$ indicating that all bulls are within the permissible limit of abnormalities and is suitable for cryopreservation.

The analysis of variance of seminal traits among all bulls revealed non-significant difference with regards to percent total morphological sperm abnormalities. Whereas other seminal parameters like volume, mass motility, sperm concentration, percent individual progressive motility and percent live sperm had a significant $(\mathrm{P}<0.05)$ difference in all Hariana bull semen.

\section{References}

Ahmad N (1994) Clinical and experimental studies of reproductive functions in the ram and male goat with special reference to the use of diagnostic ultrasound. Ph.D Thesis. Royal Vet. College. University of London.

Amrendra K, Raina VS, Mohanty TK, Gupta AK, Bishist R and Rao TKS (2011) Evalution of antioxidant for preservation of cattle semen. Indian Veterinary Journal 88(3): 37-39.

Ansari MS, Rakha BA and Shamim A (2011) Effect of Butylated Hydroxytoluene Supplementation in Extender on Motility, Plasmalemma and Viability of Sahiwal Bull Spermatozoa Pakistan Journal of Zoology 43(2): 311-314.

Bhosrekar M and Nagpaul PK (1972) Studies on effect of exercise on reaction time and semen production. Indian Journal of Veterinary science 25(3): 194-195.

Bishop MWH, Campbell RC, Hancock JL and Watson A (1954) Semen characteristics and fertility in bulls. Journal of Agriculture Science 44: 227-248.

Bloom E (1950) A minute live-dead sperm stain by means of eosin-nigrosin. Fertility and Sterility 1: 176-177.

Branton C, James CB, Patrick TE and Newson MH (1951) The relationship between certain semen quality tests and fertility and interrelationship of these tests. Journal of Dairy Science 34: 310-316.

Corona A, Cossu I, Bertulu A and Cherchi R (2006) Characterization of bacteria in fresh semen of stallions during the breeding season. Animal Reproduction Science 94: 85-88.

Correa JR and Zavos PM (1994) The hypoosmotic swelling tests: its employment as an assay to evaluate the functional integrity of frozen thawed bovine sperm membrane. Theriogenology.42: 351-360.

Dabas YPS, Verma MC and Tripathi SS (1982) Comparative study of cytomorphology of semen of some farm animals. Indian Journal of Animal Research 16(1): 10-12.

Das GC, Deori S, Das BK and Goswami RH (2007) Seminal characteristics of the swamp buffalo of Assam. Indian Veterinary Journal 184: 1052-1053.

Dhami AJ, Mohan G and Sahani KL (1998) Seasonal influence on quality and freezability of semen of Friesian and Murrah buffalo bulls. Indian Journal Animal reproduction 19(1): 55-58.

Economic survey (2009-2010) Livestock, poultry and fisheries: in Agriculture. Economic division, ministry of Finance, Govt. of India. Pp 158-159.

Erb RE, Ehlers MH and Grassner FX (1956) Metabolism of bull semen and fructolysis relationship with sperm concentration and fertility. Journal of Dairy Science 39: 326331.

Hafez ESE (1987) Semen evaluation: Reproduction in Farm Animal. Sea and Febiger, Philadelphia, PP: 455-480.

Hancock JL (1952) The morphology of bull spermatozoa. Journal of Experimental Biology 29: 445-453.

Kerur VK (1971) Studies on semeinal characteristics in Gir, Kankrej, Jaffrabadi, Surti and Murrah breeds. Indian Journal of Animal Health 10: 119-121.

Kumar A (2011). Studies on Cryopreservation of Hariana Bull Semen. MVSc Thesis. U.P. Pt. Deen Dayal Upadhyaya Pashu Chikitsa Vigyan Vishwavidyalaya Evam Go Anusandhan Sansthan, Mathura, Uttar Pradesh. 
Lasley JF (1951) Spermatozoa motility as a measure of semen quality. Journal of Animal Science 10: 211-218.

Meena GS, Raina VS, Gupta AK, Mohanty TK and Bishist R (2010) Effect of mist cooling in summer on semen quality of murrah bulls. Indian Veterinary Journal 87: 760762.

Nazir M (1988) Semen evaluation and sperm morphology - monography on reproductive pattern of Riverine buffaloes and recommendations to improve their reproductive performance at small farmer level. PARC, Islamabad.

Pant HC, Mittal AK, Kasiraj R, Prabhakar JH, Misra AK (2002) Abnormal detached heads: a characteristic morphological abnormality in spermatozoa of Holstein Friesian x Sahiwal crossbred bulls. Indian Journal of Animal Science 72(4): 316-318.

Rao AVN, Sreemanarayana O and Rao CV (1996) Studies on sex behaviour and seminal traits in Ongole, Jersey, Jersey X Ongole and Murrah bulls. Indian Veterinary Journal 73: 284-287.

Rao AVN and Sreemannarayana O (1996) Seminal traits and frozen semen production in relation to age in Murrah bulls. Indian Veterinary Journal 73: 526-30.

Salisbury GW, Vandemark NL, Lodge JR (1978) Physiology of reproduction and Artificial Insemination of Cattle. $2^{\text {nd }}$ ed. W. H. Freeman and Co. San Francisco.

Saxena VB and Tripathi SS (1981) Seasonal variations in semen characteristics and preservability in crossbred bulls. Indian Journal of Animal Research 15(1): 19-23.

Shukla DD and Bhattacharya P (1949) Studies on the semen characteristics of Indian livestock. Indian Journal of Veterinary Science and Animal Health 19: 161-169.

Singh AK (2012). Studies on certain seminal attributes and the effect of dilutors on cryopreservation of Hariana bull semen. MVSc. Thesis. U.P. Pt. Deen Dayal Upadhyaya Pashu Chikitsa Vigyan Vishwavidyalaya Evam Go Anusandhan Sansthan, Mathura, Uttar Pradesh.

Singh CM and Pangawkar GR (1990) Studies on some characteristics of exotic and crossbred bull spermatozoa. Indian Journal of Animal Research 11(2): 92-95.

Takahasi K, Vehida A and Kitao M (1990) Hypoosmotic swelling test of sperm. Arch Andrology 25: 225-242.

Tomar NS (1984) Artificial insemination and reproduction of cattle and buffaloes, 3rd edn. Saroj Prakashan Publishers Allahabad, UP, India.

Tomar NS, Mishra BS and Johari CB (1966) Seasonal variations in reaction time and semen production and prediction of some semen attributes on initial motility of spermatozoa in Hariana and Murrah bulls. Indian Journal of Dairy Science 19: 87-93.

Tomar SS and Gupta HCL (1984) Effect of season on sex drive and semen quality of Hariana bulls. Indian Journal of Animal Health 23: 37-46.

Tomar SS and Kanaujia AS (1970) Seasonal variation in reaction time and semen characteristics of Hariana bulls. Journal of Research 7(4): 541-545.

Veerapandian C, Cecilia C, Rajasekaran J and Quayam SA (1992) Testicular biometry and seminal characteristics of Kangayam bulls. Indian Journal of Animal Research 13(2): 138-140.

\section{How to cite this article:}

Ajendar Singh Pal, Vijay Singh and Akhil Patel. 2020. Studies on Seminal Attributes of Neat Semen of Hariana Bulls. Int.J.Curr.Microbiol.App.Sci. 9(01): 1742-1749.

doi: https://doi.org/10.20546/ijcmas.2020.901.194 